\title{
Behavioural and respiratory response of the shallow-water hermit crab Pagurus cuanensis to hydrostatic pressure and temperature
}

\author{
Sven Thatje ${ }^{a, *}$, Laura Casburn ${ }^{a}$, Javier A. Calcagno ${ }^{b}$ \\ ${ }^{a}$ National Oceanography Centre, Southampton, School of Ocean and Earth Science, European Way, University of Southampton, SO14 3ZH, Southampton, United Kingdom \\ b Departamento de Ecología, Genética y Evolución, Facultad de Ciencias Exactas y Naturales, Universidad de Buenos Aires - CONICET, Buenos Aires, Argentina
}

\section{A R T I C L E I N F O}

Article history:

Received 31 December 2009

Received in revised form 19 April 2010

Accepted 20 April 2010

\section{Keywords}

Anomura

Biogeography

Crustacea

Deep sea

Evolution

Physiology

\begin{abstract}
A B S T R A C T
The evolutionary history of the Anomura has long been controversially discussed. One aspect that has received little attention is the dissimilarity in physiological tolerances of the related families Paguridae and Lithodidae to environmental conditions, and how this may have determined the divergence and radiation of the families into different distribution ranges, in particular with regard to the limited penetration of the deep sea by the Paguridae. This study investigates the physiological tolerances of the temperate shallow-water hermit crab, Pagurus cuanensis, to various temperature $\left(5,10,15,20{ }^{\circ} \mathrm{C}\right)$ and pressure regimes $(1$ to 100 atm) by measuring the standard metabolic rate (SMR) and behavioural changes. SMR was primarily affected by temperature, with a notably low rate at $5{ }^{\circ} \mathrm{C}$ throughout all pressures. Behaviour was affected by pressure, with an increase in pressure from 50 to 100 atmospheres (atm) resulting in reduced activity. It is suggested that this species can tolerate hydrostatic pressures greater than those found in its natural bathymetric range. It is discussed that a lack of physiological cold tolerance and ecological factors, such as the need to find gastropod shells for protection, are the principal restrictions maintaining P. cuanensis to a maximum depth of approximately $250 \mathrm{~m}$. We hypothesize that temperate shallow-water invertebrates could indeed be able to penetrate greater depths as continental shelf waters warm up in the course of global climate change.
\end{abstract}

(C) 2010 Elsevier B.V. All rights reserved.

\section{Introduction}

The horizontal and vertical distribution ranges of marine organisms are controlled by a combination of biotic and abiotic factors (Carney et al., 1983). The two major abiotic factors that vary with depth are temperature and hydrostatic pressure. In relation to the depth distribution range of a species, the combined tolerance of temperature and hydrostatic pressure is potentially paramount in determining the upper and lower limits of the vertical region occupied by that species. The effect of temperature on the bathymetric distribution of marine organisms has been widely studied (e.g. Southward et al., 1995). However, hydrostatic pressure as a significant limiting factor has received relatively little attention in the past (Brauer et al., 1975; Jaenicke, 1983) and/or such studies have been constrained by the lack of available technology (Shillito et al., 2001; Robinson et al., 2009). Understanding the mechanisms by which these factors combined can drive the distribution limitations of species may advance comprehension of local biodiversity, as well as the potential for future radiation of species outside of their current range - an aspect particularly relevant in light of future climate change and the warming of surface waters (Tyler and Young, 1998).

\footnotetext{
* Corresponding author. Tel.: +442380 596449; fax: +44 2380593059 E-mail address: svth@noc.soton.ac.uk (S. Thatje).
}

The origin of deep-sea animals has been debated since the middle of the 19th Century (for review see Gage and Tyler, 1991). A relationship between the anomuran families Lithodidae (king crabs) and the Paguridae (hermit crabs) was first suggested by Milne Edwards (1836), in part due to the large, fleshy, asymmetrical abdomen of the king crabs (McLaughlin, 1983). It has been suggested that the large, primarily deep-sea king crabs (Feldmann, 1998) were descended from the small, primarily intertidal shell-dwelling hermit crabs through the process of 'carcinization'. The process of carcinization involves a long membranous abdomen becoming transformed into a reduced state, folded under the thorax and pressed against the sternum, negating the need for further protection of the abdomen from a gastropods shell or similar (McLaughlin and Lemaitre, 1997). Furthermore, this transition from hermit crabs to king crabs likely coincided with an increase in the abundance of the laminarid kelps (Saunders and Druehl, 1992; McGaw and Duff, 2008), which may have provided protection from predation and thus allowed the loss of the gastropod shell shelter. This hypothesis suggested the initial evolution of the soft-abdomen lithodids, followed by the fully carcinized subfamily Lithodinae (Zaklan, 2002; McGaw and Duff, 2008). Cunningham et al. (1992) assessed ribosomal RNA of both families and found close similarities between Pagurus and Lithodes species, placing the king crabs within the genus Pagurus, as well as estimating that the transition occurred between 13 and 25 million years ago. This is more than 50 million years later than the period from which fossils assigned to the genus Pagurus have been 
found (Cunningham et al., 1992, and references therein). On the other hand, there have also been noteworthy studies refuting the relationship between the king and hermit crabs. Martin and Abele (1986) first tentatively suggested that the close relationship proposed might not be correct (McLaughlin et al., 2007). In 1997, McLaughlin and Lemaitre strongly opposed the traditional view of lithodid crabs being descendant from hermit predecessors through carcinization based on their study on adult morphology. They even suggested an alternative hypothesis; that in fact the reverse had occurred, and that hermit crabs had evolved from the crab-like lithodid form (McLaughlin et al., 2004, 2007)

Species of the family Paguridae are distributed globally demonstrating a wide range of thermal tolerances from subpolar to tropical environments. A few exceptional species are also found terrestrially (Hazlett, 1981), while only few species are found in the deep sea (Selbie, 1921). The family Lithodidae is divided into two sub-families, the Hapalogastrinae which is constrained to the shallow North-Pacific and the Lithodinae, which is distributed globally but primarily restricted to the cold waters of the deep sea and shallow waters of high latitudes (Hall and Thatje, 2009). Differences in the distributions of the families may be related to the evolution of different tolerance levels to both temperature and hydrostatic pressure. The radiation of the Lithodinae into the deep sea from an intertidal ancestral state may concur with the pattern of onshore to offshore migration of species previously suggested (Jablonski et al., 1983).

This study will for the first time elucidate whether physiological limits have impaired a widespread invasion of the deep sea by the Paguridae. The study of the factors that govern the distribution ranges of both Lithodidae and Paguridae provides a case for physiological tolerances contributing to the constraint and radiation of other taxa into and through deep-sea environments.

\section{Materials and methods}

\subsection{Sampling and maintenance}

Individuals of the hermit crab Pagurus cuanensis were collected from Southampton Water, England, by dredging between August and October, 2008. Animals were maintained in approximately $10 \mathrm{l}$ tanks containing filtered seawater (29 psu) and aeration; water was partially changed twice a week. The desired temperature, approximately $15 \pm 1{ }^{\circ} \mathrm{C}$ (average water temperature in Southampton Water during September), was maintained by keeping the tanks in Cooled Incubators. To avoid cannibalism, the animals were kept separate by placing each into a small glass dish, which were then covered with a plastic grid. Feed consisted of shrimp food pellets, one pellet each administered every Monday and Friday. Hermit crabs were marked for identification using small numbered bee tags glued to their shells. In order to acclimatize the experimental animals and provide time to recover from collection and handling stress they were kept under these conditions for a minimum of a week prior to use. No mortality was recorded as a result of the sampling and maintenance conditions. When the three further experimental temperatures $\left(5,10\right.$ and $\left.20^{\circ} \mathrm{C}\right)$ were required, the temperature of the incubators was altered by a maximum of $1.5^{\circ} \mathrm{C}$ per day and animals were allowed to acclimatize for a minimum of 5 days once the desired temperature was reached. No animal was used for an experiment more than once.

To reduce handling stress, animal parameters (Carapace Length $=$ CL, weight, sex) were obtained following each experiment. In order to release the hermit crab from its shell, the shell was gently crushed in a vice, which makes the animal emerge from its shell and so could be slowly pulled away with forceps; a method that has been used previously and does not appear to cause injury or any mortality (Briffa and Elwood, 2005). Crabs were then thoroughly dried with blotting tissue and weighed to the nearest $1 / 100 \mathrm{~g}$ to determine the wet mass. Animals of both sexes were used.

\subsection{Respiration rates}

Hermit crabs were deprived of food for 4 days prior to the experiment to minimize errors in oxygen consumption due to bacteria in faeces. Prior to each experiment two plastic (1 1) containers, one containing filtered $(30 \mu \mathrm{m})$ seawater and the other containing fresh tap water, along with six small pressure vessels were placed inside an incubator until the desired temperature for each test $(5,10,15$, $20{ }^{\circ} \mathrm{C}$ ) was reached. The seawater was aerated for $30 \mathrm{~min}$. The aeration system was removed 30 min before the start of each experiment to ensure that the water was fully oxygen saturated yet no longer contained air bubbles. An individual hermit crab was placed inside a $50 \mathrm{ml}$ transparent plastic vial which was then filled with the oxygen saturated, filtered seawater and closed underwater to ensure that no air bubbles were trapped inside. The vial was placed inside a small pressure vessel that had been incubated at the experimental temperature (for details see Mestre et al., 2009), which was filled with the fresh tap water previously incubated. When required, the pressure vessel was pressurized to the desired level $(20,50,100 \mathrm{~atm})$ using a hydraulic (Maximator, Germany) hand pump. The increase in pressure was continuous and acute, taking $10 \mathrm{~s}$ or less. After $1 \mathrm{~h}$ the pressure vessel was removed from the incubator and the pressure released instantaneously. The plastic vial was removed and inverted gently three times to ensure the oxygen content of the seawater was homogenously mixed. The lid was then removed carefully to ensure no water was spilt. Using the microoptode and temperature sensor the oxygen percentage concentration and temperature were measured and recorded.

\subsection{Standard metabolic rate}

Oxygen was measured using a temperature controlled oxygen meter and microoptode (Microx TX 3, Presens, Germany). The microoptode was calibrated daily prior to use at the experimental temperature with $0 \%$ oxygen saturation as a seawater solution oversaturated with sodium sulphite $\left(\mathrm{Na}_{2} \mathrm{SO}_{3}\right)$ and $100 \%$ oxygen saturation as fully aerated seawater that had been left to settle for $30 \mathrm{~min}$. Oxygen measurements were temperature compensated using a temperature probe (PT 1000) positioned in close proximity (within $\mathrm{mm}$ ) to the microoptode.

In order to measure the concentration of oxygen in the $100 \%$ oxygen saturated seawater prior to experimental use, the temperature and salinity of the seawater were measured. The temperature was measured using a temperature probe and the salinity was measured using a Hanna Instruments HI 9828 multiparameter water quality meter. The concentration of oxygen in $100 \%$ saturated seawater ( $\mu \mathrm{mol} \mathrm{O}_{2} \mathrm{l}^{-1}$ ) was calculated using the equation from Benson and Krause (1984) (Eq. (1)):

$$
\begin{aligned}
\text { In } C *_{0}= & -135.90205+1.575701 \times 10^{5} / T-6.642308 \times 10^{7} / T^{2} \\
& +1.243800 \times 10^{10} / T^{3}-8.621949 \times 10^{11} / T^{4} \\
& -S\left(0.017674-10.754 / T+2140.7 / T^{2}\right)
\end{aligned}
$$

where $\mathrm{C}^{*}{ }_{\mathrm{O}}$ is the concentration of oxygen in $100 \%$ saturated filtered seawater $\left(\mu \mathrm{mol} \mathrm{O} \mathrm{O}_{2} \mathrm{l}^{-1}\right), T$ is the temperature in Kelvin and $S$ is the salinity. In this experiment the conditions were at atmospheric pressure and within the $0{ }^{\circ} \mathrm{C}<T<40{ }^{\circ} \mathrm{C}$ and $0<S<40$ boundaries set by Benson and Krause (1984). To determine anomalies caused by minor differences in seawater and in the calibration of the microoptode, the end point percentage oxygen saturation of the control vial containing only seawater was subtracted from $100 \%$.

The percentage oxygen saturation in each sample at the end of each experiment $\left(\% \mathrm{O}_{2}\right.$ end $)$ was calculated by subtracting this difference from the end point \% oxygen saturation value measured in each vial using the microprobe. 
The ratio of the percentage oxygen saturation in the sample at the end of each experiment $\left(\% \mathrm{O}_{2}\right.$ end $)$ to the $100 \%$ oxygen saturation $\left(\mathrm{C}^{*}{ }_{\mathrm{O}}\right)$ was used to determine the oxygen concentration $\left(\mathrm{CO}_{2}\right)$ in each sample $\left(\mu \mathrm{mol} \mathrm{O} \mathrm{O}^{-1}\right.$ ) (Eq. (2)):

$\left(\mathrm{CO}_{2}\right)=\left(\mathrm{C}_{0}^{*} . \% \mathrm{O}_{2}\right.$ end $) / 100$

Since each vial was a closed system, the oxygen consumption rate $\left(\mathrm{rO}_{2}\right)$ of each individual hermit $\left(\mu \mathrm{mol} \mathrm{O} \mathrm{O}_{2} \mathrm{~h}^{-1}\right)$ could then be calculated using the following (Eq. (3)):

$\left(\mathrm{rO}_{2}\right)=\left(\mathrm{CO}_{2}\right.$ start $-\mathrm{CO}_{2}$ end $) \times \mathrm{V} / \mathrm{t}$

where $\mathrm{CO}_{2}$ start is the oxygen concentration prior to closure of the vials, $\mathrm{CO}_{2}$ end is the oxygen concentration when the vial is reopened at the end of the experiment (both in $\mu \mathrm{mol} \mathrm{O}_{2} \mathrm{~h}^{-1}$ ), $\mathrm{V}$ is the volume of water in each vial in liters and $t$ is the time each vial is closed in hours.

The volume of water inside each vial was measured by pouring the water into a $100 \mathrm{ml}$ container on zeroed scales and recording the weight ( $1 \mathrm{ml}=1 \mathrm{~g})$, whilst the hermit crab was held inside the vial. The vial was inverted twice and the hermit tapped to ensure that water was not trapped inside the shell. Five replicates were conducted for each pressure at each temperature. For each test condition a control was run. In order to eliminate any bias due to bacterial oxygen demand or calibration, any difference in oxygen concentration of the control vial from $100 \%$ was subtracted from the values of the experimental vials.

\subsection{Behavioural measurements}

Behavioural measurements were taken using the IPOCAMP ${ }^{\mathrm{TM}}$ pressure system (Shillito et al., 2001). The IPOCAMP ${ }^{\mathrm{TM}}$ was set running for $1 \mathrm{~h}$ prior to the start of each test to ensure that the saltwater inside was maintained at the desired test temperature $\left(5,10,15,20^{\circ} \mathrm{C}\right)$. A hermit crab was selected at random and its shell secured to a clear plastic Petri dish using dental wax, ensuring that the opening of the shell faced upwards so that the hermit crab could be viewed from above at all times unless it was completely withdrawn inside the shell. This was then placed inside the IPOCAMP ${ }^{\mathrm{TM}}$ upon a tripod platform, which raised the position of the hermit crab inside the pressure chamber, allowing it to be viewed more clearly using en endoscope (see Ravaux et al., 2003). The IPOCAMP ${ }^{\mathrm{TM}}$ was then set running at atmospheric pressure for $30 \mathrm{~min}$ to allow the hermit crab to acclimatize and recover from handling stress. The video recorder was then set to record and the pressure altered at 20 min intervals from 1 atm-20 atm$50 \mathrm{~atm}-100 \mathrm{~atm}-50 \mathrm{~atm}-20 \mathrm{~atm}-1 \mathrm{~atm}$, inclusive of the $20 \mathrm{~min}$ at atmospheric pressure at the start and end of each experiment. Repeats were conducted $(N=5)$ for each of the experimental temperatures $\left(5,10,15,20^{\circ} \mathrm{C}\right)$. For the purpose of this study only the increase in pressure was analysed for comparison with SMR.

\subsection{Video analysis}

The videos were analysed using the software package Ulead. Behaviour was not recorded for the initial 5 min after an increase or decrease of pressure to allow the hermit crab to recover from any initial shock caused by the changing pressure. Behaviours were divided into two categories - states and events, depending on the relative length of time over which each behavioural incident occurred (Baeza and Fernández, 2002). Behaviours classed as states consisted of an action or position, which occurred over a period greater than $10 \mathrm{~s}$ (e.g. remaining withdrawn within the shell). Behaviour classed as events consisted of single specific actions or movements, which were completed in less than $10 \mathrm{~s}$ (e.g. wiping of the eye stalks with the third maxillipeds). States were quantified as proportion of time spent in each behavioural state (\% of each 15 min period). Events were quantified as frequency of oc- currences per unit time (15 min). The states and events recorded were as follows:

\section{States}

- 'Intermediate' (Fig. 1A) - time spent in a 'relaxed' position, with the chela, front two pairs of legs, eyestalks and front of the carapace clearly visible, but the soft abdomen held inside the shell not visible. Very little movement of the body was observed.

- 'Escaping' (Fig. 1B) - time spent extended further out of the shell than the 'Intermediate' position, with the soft abdomen visible and the hermit crab actively exploring where the shell was fixed with the dental wax and attempting to free itself. Movement of the body was almost continuous.

- 'Withdrawn' (Fig. 1C) - time spent with both the soft abdomen and the carapace hidden within the shell, either with legs withdrawn into the shell yet still visible, or totally withdrawn out of sight. No visible movement.

- 'Emerging' (Fig. 1D) - time spent moving between 'withdrawn' and 'intermediate' states as the hermit crab emerged from its protected position within the shell. This movement was often non continuous with many pauses; however, from the initial emerging motion to reaching the 'intermediate' state was counted.

States were recorded as total time spent in each state during each 15 min period under each pressure.

\section{Events}

Events primarily consisted of wiping of appendages with the third maxillipeds. The frequency of wipes of each type of appendage was counted for each $15 \mathrm{~min}$ period (excluding the initial $5 \mathrm{~min}$ after a pressure change) for each pressure. The individual events were defined as follows:

- Wiping of eye stalk/s - Number of times the third maxillipeds were used to wipe one or both eyestalks, placed behind the eye stalk/s and moved along from the base towards the end.

- Wiping of scaphognatites and antennule/s - Number of times the third maxillipeds were used to wipe the scaphognatites and one or both of the antennules, placed behind the scaphognatites and antennules and wiped with a downward motion.

- Wiping of antennae - Number of times the third maxillipeds were used to wipe one antennae i.e. placed behind the antennae and wiped along the length from the base towards the end.

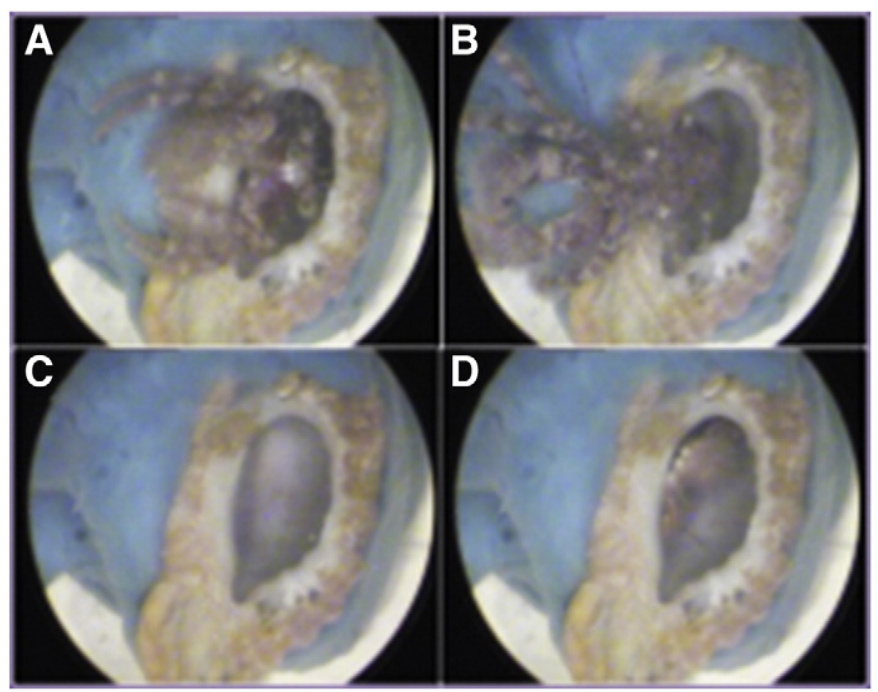

Fig. 1. The four behavioural states of Pagurus cuanensis in $\mathrm{IPOCAMP}^{\mathrm{TM}}$; (A) Intermediate, (B) Escaping, (C) Withdrawn, and (D) Emerging. 
- Wiping of pereiopods - Number of times the third maxillipeds were used to wipe one of the pereiopods, placed partway down and wiped towards the end.

- Withdrawal - Number of times the hermit crab retreated further into the shell than the 'intermediate' position, often indicated by a sudden movement.

For events such as third maxilliped wiping of eye stalks, scaphognatites and antennules, each wiping motion was counted, regardless of whether one or both of each pair were wiped at a time. However, if more than one type of appendage was wiping simultaneously, this was counted as one event for each type of appendage. Scaphognatites were always wiped in the same motion as the antennules and therefore were grouped together.

\subsection{Statistical analyses}

Data transformation was necessary as the variances were heterogeneous (Underwood, 1981). The oxygen and behavioural events were found to have increasing variance with mean and therefore were square root transformed. However, as a large proportion of the behavioural events data were zero the transformation was completed using the square root of $n+1$. The behavioural states were proportions and therefore were arc-sine square root transformed. The data were analysed using Two-way Repeated Measures ANOVA. The post-hoc, multiple comparisons Holm-Sidak test (Sokal and Rohlf, 1995) was then used to determine which treatments produced the differences. As the data failed the normality test, 0.01 confidence limits were applied as opposed to the typical 0.05 to ensure statistically significant differences were not reported in error (Underwood, 1981).

\section{Results}

\subsection{Effects of temperature on SMR when subjected to hydrostatic pressure}

The standard metabolic rate (SMR) scaled with temperature (Fig. 2). However, the effect of temperature on the SMR was dependant on the pressure condition. At atmospheric pressure an increase in temperature resulted in an overall increase of the SMR. The smallest mean SMR was at $5^{\circ} \mathrm{C}$ at $1.63 \pm 0.47 \mu \mathrm{molO}_{2} \mathrm{~h}^{-1} \mathrm{~g}^{-1}$, the largest mean SMR was at $20^{\circ} \mathrm{C}$ at $35.74 \pm 16.31 \mu \mathrm{molO}_{2} \mathrm{~h}^{-1} \mathrm{~g}^{-1}$. In addition, the standard deviation increased with temperature. The two intermediate temperatures, 10 and $15{ }^{\circ} \mathrm{C}$, however resulted in similar SMRs and standard deviations $\left(15.51 \pm 6.59\right.$ and $14.41 \pm 6.74 \mu \mathrm{molO}_{2} \mathrm{~h}^{-1} \mathrm{~g}^{-1}$, respec-

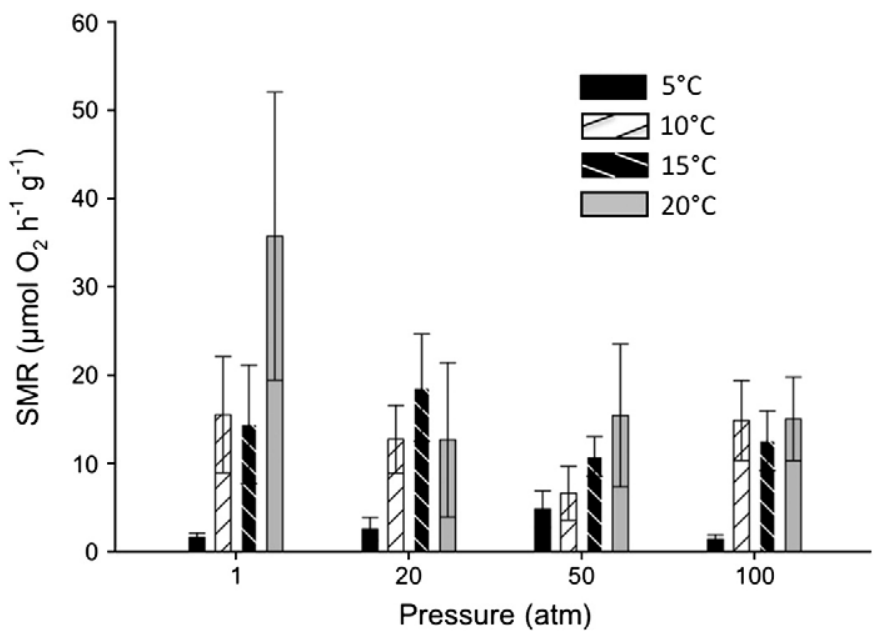

Fig. 2. Pagurus cuanensis. Standard metabolic rate $\left(\mu \mathrm{mol} \mathrm{O}_{2} \mathrm{~h}^{-1} \mathrm{~g}^{-1}\right)$ maintained under temperature and pressure conditions for $1 \mathrm{~h}$; $(N=5$ in each treatment). tively). At 20 atm the effect of temperature on SMR was less clear. For the three lower temperatures, SMR increased with temperature; however the SMR at $20^{\circ} \mathrm{C}$ decreased to $12.66 \pm 8.74 \mu \mathrm{molO}_{2} \mathrm{~h}^{-1} \mathrm{~g}^{-1}$, lower than the SMR of 10 and $15^{\circ} \mathrm{C}$, indicating the surpass of a physiological threshold. At $50 \mathrm{~atm}$, the SMR also increased with temperature, but to a less distinctive degree than at $1 \mathrm{~atm}$. In contrast, at $100 \mathrm{~atm}$ the three higher temperatures $\left(10,15\right.$ and $\left.20^{\circ} \mathrm{C}\right)$ were relatively similar, while the SMR at $5{ }^{\circ} \mathrm{C}$ the SMR remained low at $1.39 \pm$ $0.52 \mu \mathrm{molO}_{2} \mathrm{~h}^{-1} \mathrm{~g}^{-1}$.

\subsection{Effect of pressure on SMR at different temperatures}

The effect of pressure on SMR was dependent upon the experimental temperature, with each temperature showing different relationships of SMR with pressure (Fig. 2). At $5{ }^{\circ} \mathrm{C}$ the SMR was the lowest at all pressures, however an increase in pressure caused a steady increase of SMR from $1 \mathrm{~atm}$ to $50 \mathrm{~atm}(1.63 \pm 0.466$ to $4.82 \pm$ $\left.2.07 \mu \mathrm{molO}_{2} \mathrm{~h}^{-1} \mathrm{~g}^{-1}\right)$. The SMR then decreased at $100 \mathrm{~atm}$ to $1.39 \pm$ $0.52 \mu \mathrm{molO}_{2} \mathrm{~h}^{-1} \mathrm{~g}^{-1}$, a similar value to that at $1 \mathrm{~atm}$. In contrast, at $10{ }^{\circ} \mathrm{C}$ the SMR displayed the inverse of this pattern, decreasing slightly from $1 \mathrm{~atm}$ to $20 \mathrm{~atm}\left(15.51 \pm 6.59\right.$ to $\left.12.73 \pm 3.86 \mu \mathrm{molO}_{2} \mathrm{~h}^{-1} \mathrm{~g}^{-1}\right)$, and more sharply to $6.60 \pm 3.04 \mu \mathrm{molO}_{2} \mathrm{~h}^{-1} \mathrm{~g}^{-1}$ at $50 \mathrm{~atm}$. The SMR then increased at $100 \mathrm{~atm}$ to $14.86 \pm 4.54 \mu \mathrm{molO}_{2} \mathrm{~h}^{-1} \mathrm{~g}^{-1}$. At $15^{\circ} \mathrm{C}$ the SMR increased from 1 to $20 \mathrm{~atm}$ from $14.41 \pm 6.74$ to $18.55 \pm$ $6.08 \mu \mathrm{molO}_{2} \mathrm{~h}^{-1} \mathrm{~g}^{-1}$. The SMR then decreased at $50 \mathrm{~atm} 10.76 \pm$ $2.25 \mu \mathrm{molO}_{2} \mathrm{~h}^{-1} \mathrm{~g}^{-1}$, and increased again to $12.65 \pm 3.36 \mu \mathrm{molO} \mathrm{O}_{2}$ $\mathrm{h}^{-1} \mathrm{~g}^{-1}$ at $100 \mathrm{~atm}$. At $20{ }^{\circ} \mathrm{C}$, the SMR at $1 \mathrm{~atm}$ was much higher than the other temperatures, at $35.74 \pm 16.31 \mu \mathrm{molO}_{2} \mathrm{~h}^{-1} \mathrm{~g}^{-1}$. This value decreased by 23.08 to $12.66 \pm 8.74 \mu \mathrm{molO}_{2} \mathrm{~h}^{-1} \mathrm{~g}^{-1}$ at $20 \mathrm{~atm}$, increased slightly at $50 \mathrm{~atm}$ to $15.42 \pm 8.09 \mu \mathrm{molO}_{2} \mathrm{~h}^{-1} \mathrm{~g}^{-1}$ and remained fairly constant to $100 \mathrm{~atm}$.

A statistical interaction was found between the effects of temperature and pressure on SMR $(F=5.052, p<0.001)$. Temperature also had a significant effect on SMR $(F=47.471, p<0.001)$. A Holm-Sidak post-hoc multiple comparison test found that these differences were between the $5{ }^{\circ} \mathrm{C}$ and the higher three temperatures, as well as between 10 and $20^{\circ} \mathrm{C}$.

\subsection{Effects of temperature and pressure on behavioural events}

The effects of temperature and pressure on the rate of wiping of the eyestalks and with the third maxillipeds (Fig. 3) were nonsignificant. However, the lowest rate of wiping was consistently found at $5{ }^{\circ} \mathrm{C}$, which decreased with pressure, and the highest rate was at

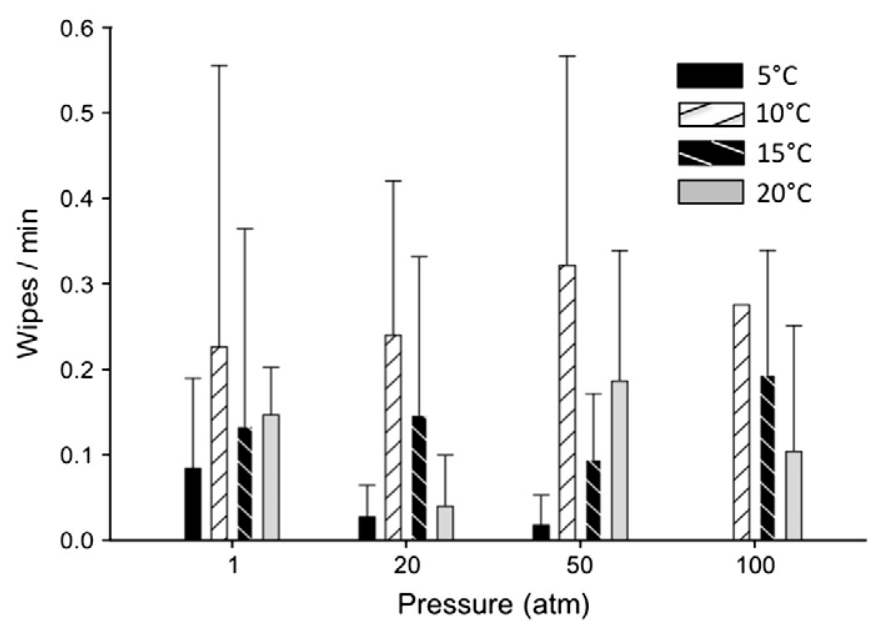

Fig. 3. Pagurus cuanensis. Frequency of wiping of the eyestalks with the third maxillipeds under different temperature and pressure conditions; ( $N=5$ in each treatment). 


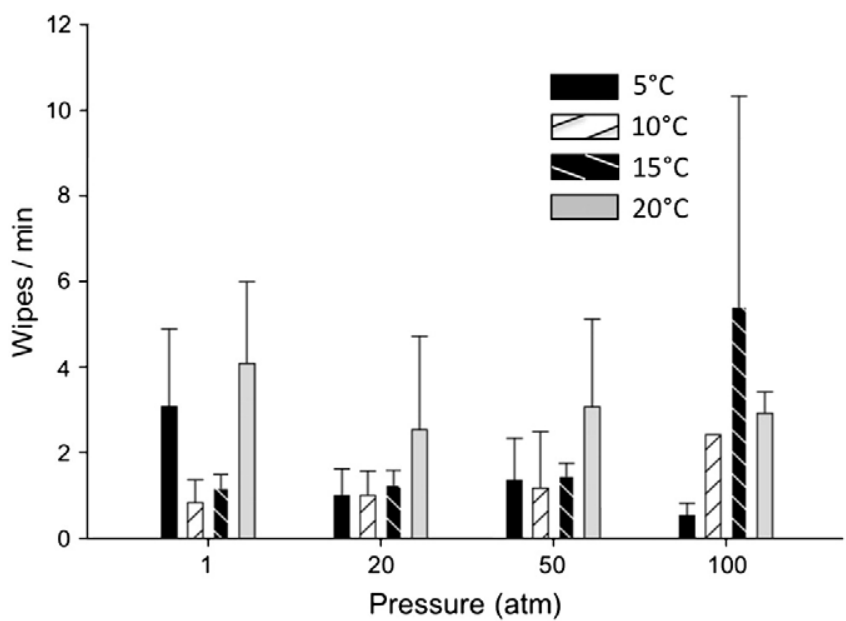

Fig. 4. Pagurus cuanensis. Frequency of wiping of the scaphognatites and antennules with the third maxillipeds under different temperature and pressure conditions; $(N=5$ in each treatment).

$10{ }^{\circ} \mathrm{C}$ at all pressures. The effects of temperature and pressure (Fig. 4) showed a significant interaction on the rate of wiping of the scaphognatites and antennules $(F=3.999, p<0.001)$. At $1 \mathrm{~atm}$ the frequency of wiping was low at 10 and $15^{\circ} \mathrm{C}$, at $0.83 \pm 0.53$ and $1.17 \pm$ 0.32 wipes $\mathrm{min}^{-1}$, respectively. The rate of wiping of the antennules was higher at 5 and $20^{\circ} \mathrm{C}$ at $3.08 \pm 1.81$ and $4.08 \pm 1.90$ wipes $\mathrm{min}^{-1}$, respectively.

At 20 atm the rate of wiping of the scaphognatites and antennules at $5{ }^{\circ} \mathrm{C}$ was reduced to a similar value to 10 and $15^{\circ} \mathrm{C}$, the rate of which remained stable. The rate at $20^{\circ} \mathrm{C}$ also decreased by a lesser extent to $2.54 \pm 2.18$. The values at all temperatures remained relatively unchanged at $50 \mathrm{~atm}$, although at each temperature the rate marginally increased by an average of 0.3 wipes $\mathrm{min}^{-1}$. At $100 \mathrm{~atm}$ the rate of wiping of the scaphognatites and antennules at $5{ }^{\circ} \mathrm{C}$ decreased to its lowest value at $0.53 \pm 0.28$ wipes $\min ^{-1}$, at 10 and $15^{\circ} \mathrm{C}$ the rates increased to the highest values for each temperature $(2.41 \pm 0.00$ and $5.40 \pm 4.92)$. However, at $20^{\circ} \mathrm{C}$ the rate remained very similar to that at $50 \mathrm{~atm}$. The standard deviations were largest at $20{ }^{\circ} \mathrm{C}$ except for at $100 \mathrm{~atm}$ where the distinctly large standard deviation was at $15^{\circ} \mathrm{C}(4.92)$.

The rate of wiping of the antennae with the third maxillipeds (Fig. 5) was significantly affected by pressure $(F=15.778, p<0.001)$.

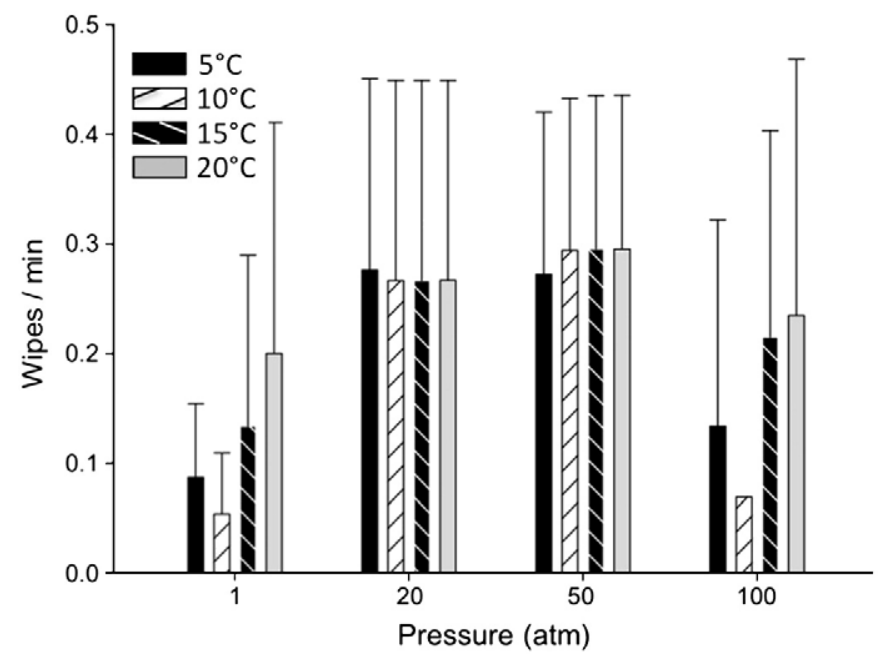

Fig. 5. Pagurus cuanensis. Frequency of wiping of the antennae with the third maxillipeds under different temperature and pressure conditions; ( $N=5$ in each treatment).

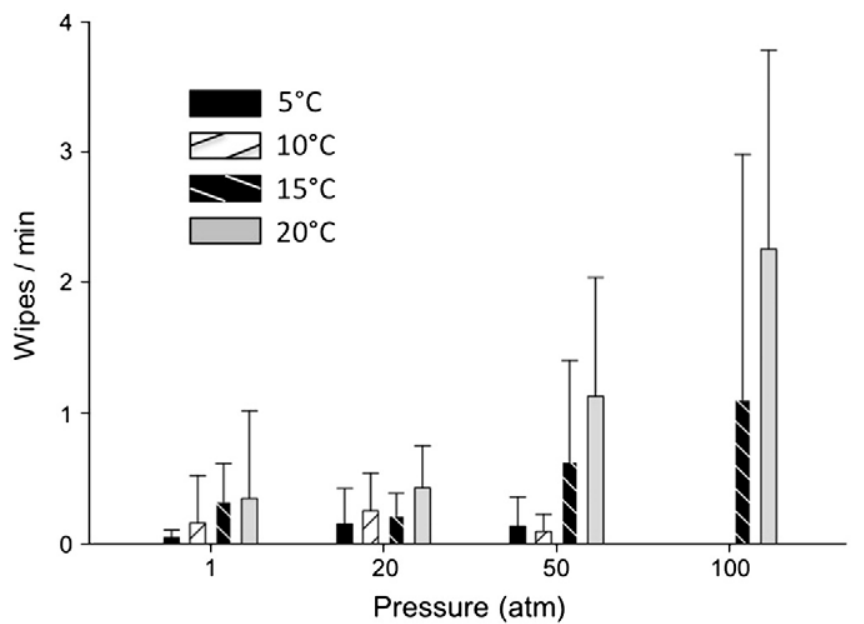

Fig. 6. Pagurus cuanensis. Frequency of wiping of the pereiopods with the third maxillipeds under different temperature and pressure conditions; ( $N=5$ in each treatment).

Furthermore, the frequency of antennae wiping at both 1 and $100 \mathrm{~atm}$ was statistically different to 20 and $50 \mathrm{~atm}(p<0.001)$. The rate of wiping of the antennae reached a maximum at all temperatures at 20 and $50 \mathrm{~atm}$, while the rate of wiping was lower and more affected by temperature at 1 and $100 \mathrm{~atm}$. At $1 \mathrm{~atm}$ the rate of wiping showed an overall increase with temperature to a maximum at $20^{\circ} \mathrm{C}$ of $0.200 \pm$ 0.021 wipes $\mathrm{min}^{-1}$. At 20 and $50 \mathrm{~atm}$, the wiping at all temperatures increased to similar values of approximately 0.3 wipes $\min ^{-1}$. At $100 \mathrm{~atm}$ the pattern of rates of wiping for each temperature resembled that at $1 \mathrm{~atm}$.

There was no significant difference with temperature or pressure found for the rate of wiping of the pereiopods with the third maxillipeds. However, the results show that at each pressure there was a general increase in rate of wiping with temperature (Fig. 6). At 5 and $10{ }^{\circ} \mathrm{C}$ the values remained low and decreased to zero at $100 \mathrm{~atm}$, while the rates of wiping at 15 and $20^{\circ} \mathrm{C}$ increased at $50 \mathrm{~atm}$ and increased again at 100 atm up to $1.100 \pm 1.880$ and $2.256 \pm 1.524$, respectively.

At the three lower pressures $(1,20,50 \mathrm{~atm})$ the mean number of withdrawals into the shell per minute remained low at less than 0.6 withdrawals $\min ^{-1}$ at all temperatures (Fig. 7), with no withdrawals at 10 and $15{ }^{\circ} \mathrm{C}$. At 100 atm the rate of withdrawals at $5{ }^{\circ} \mathrm{C}$ decreased to 0 , while the rate for 10 and $20^{\circ} \mathrm{C}$ increased to $1.40 \pm 2.07$

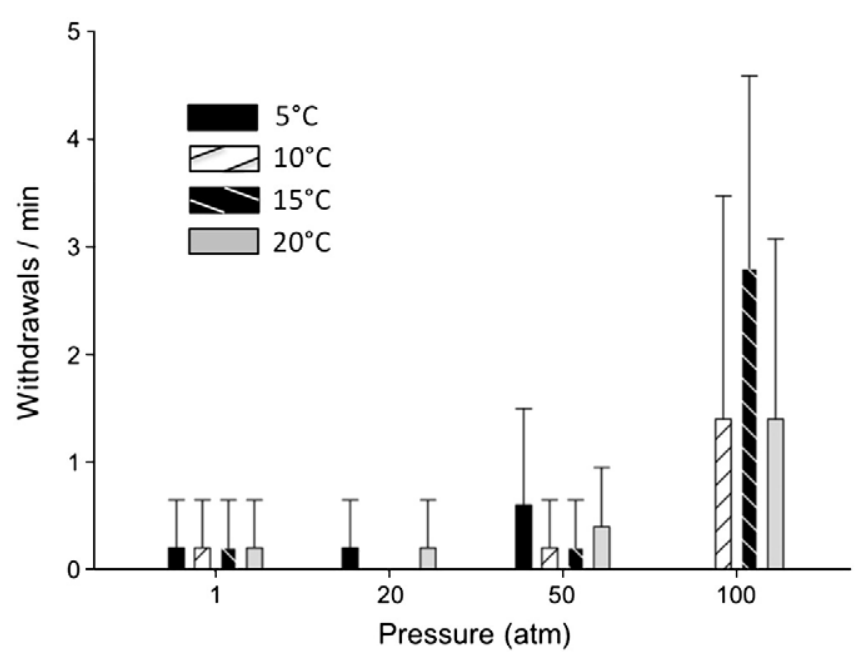

Fig. 7. Pagurus cuanensis. Frequency of withdrawals into the shell under different temperature and pressure conditions; ( $N=5$ in each treatment). 


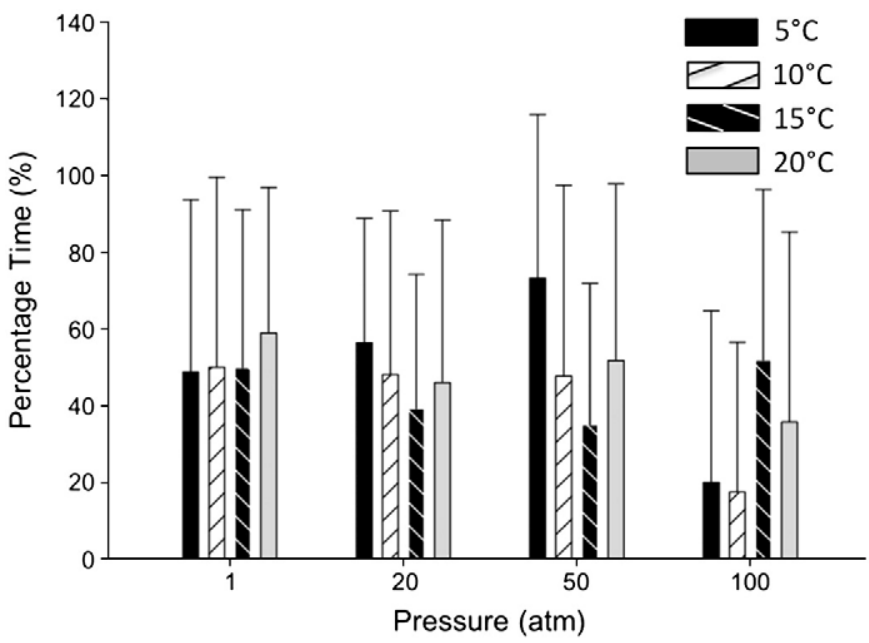

Fig. 8. Pagurus cuanensis. Percentage of time spent in the intermediate state under different temperature and pressure conditions; ( $N=5$ in each treatment).

and $1.40 \pm 1.67$ withdrawals $\min ^{-1}$, respectively. At $15^{\circ} \mathrm{C}$ the rate also increased but to a rate twice that of 10 and $20^{\circ} \mathrm{C}$, to $2.80 \pm 1.79$. Care must be taken when analyzing this behaviour, as it indicates the number of withdrawals per minute, not the amount of time withdrawn. If a hermit was already withdrawn when data collection for a pressure began and remained withdrawn throughout, the number of withdrawals per minute is still zero (e.g. $5{ }^{\circ} \mathrm{C}$ at $100 \mathrm{~atm}$ ). Therefore this behavioural event, withdrawing, should be compared with the behavioural state withdrawn (see Fig. 10). Statistical analysis found a significant effect of pressure $(F=13.108, p<0.001)$ and also a significant interaction between the effects of temperature and pressure $(F=3.734, p=0.001)$.

\subsection{Effects of temperature and pressure on behavioural states}

There was no significant effect of pressure or temperature on the percentage of time spent in the intermediate 'resting' position, which remained almost constant at each temperature and pressure (Fig. 8). The percentage of time spent in the escaping state (Fig. 9) was significantly affected by pressure $(F=7.080, p<0.001)$, with the lowest average values for 10,15 and $20^{\circ} \mathrm{C}$ at $100 \mathrm{~atm}$, and the lowest value for $5{ }^{\circ} \mathrm{C}$ at 50 atm (Fig. 9). Post hoc comparisons placed the significant differences between $100 \mathrm{~atm}$ and each of the lower three pressures. With the exception of $5{ }^{\circ} \mathrm{C}$, where the lowest average percentage of

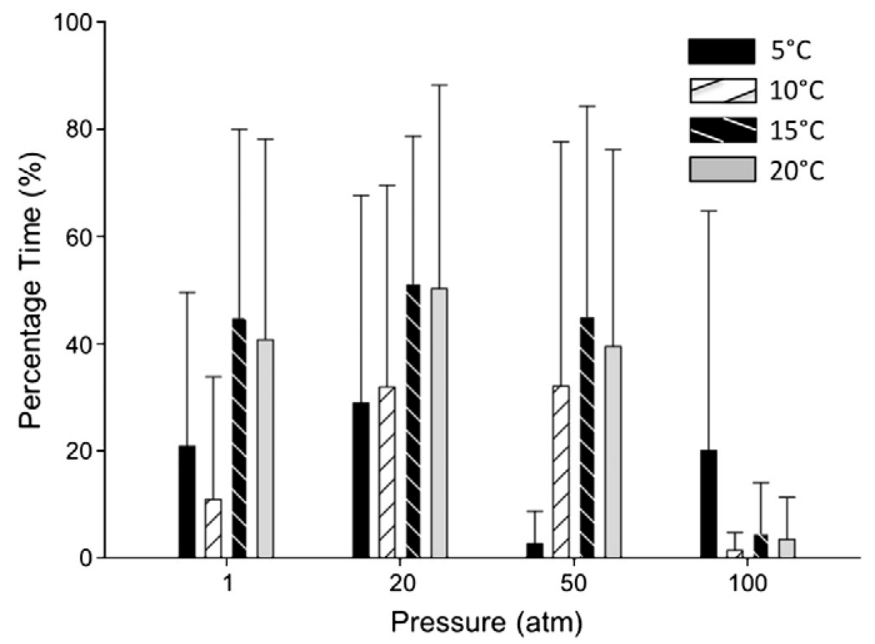

Fig. 9. Pagurus cuanensis. Percentage of time spent in the escaping state under different temperature and pressure conditions; ( $N=5$ in each treatment).

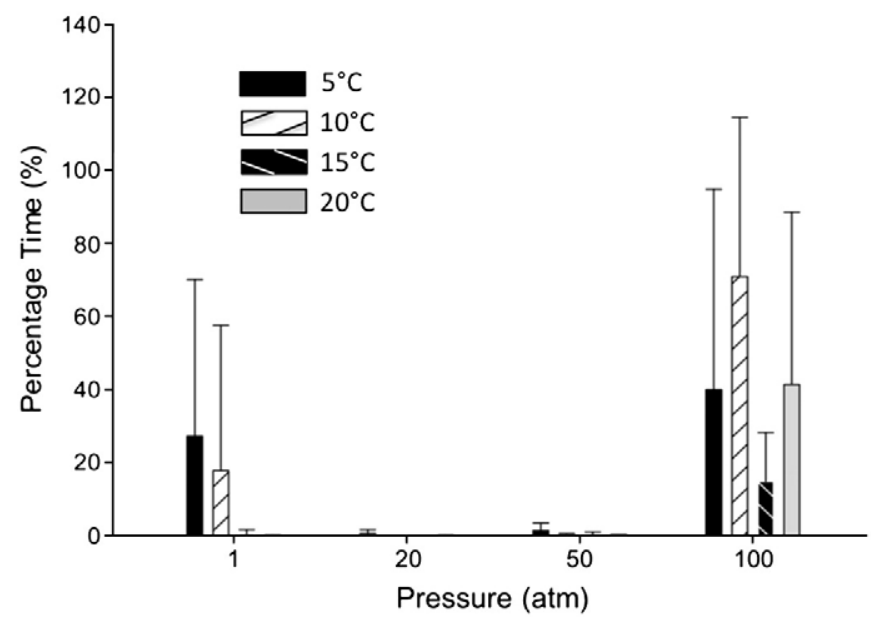

Fig. 10. Pagurus cuanensis. Percentage of time spent in the withdrawn state under different temperature and pressure conditions; $(N=5$ in each treatment).

time escaping was found at $50 \mathrm{~atm}(2.71 \pm 6.06 \%)$, the lowest percentage of time spent escaping was at $100 \mathrm{~atm}$. The highest percentage of time spent attempting to escape was found at $20 \mathrm{~atm}$ at all temperatures, with the highest average value of $51.22 \pm 27.41 \%$ at $15^{\circ} \mathrm{C}$.

The percentage of time spent withdrawn was negligible at all temperatures at 20 and $50 \mathrm{~atm}$ and at 15 and $20^{\circ} \mathrm{C}$ at $1 \mathrm{~atm}$ (Fig. 10). At $1 \mathrm{~atm}$ the animals spent an average of 27.18 and $17.78 \%$ of time escaping at 5 and $10^{\circ} \mathrm{C}$, respectively. The percentage of time spent withdrawn was highest at every temperature at $100 \mathrm{~atm}$, with the highest mean value at $10^{\circ} \mathrm{C}$ of $70.87 \pm 43.55 \%$. There was a significant difference with pressure $F=12.533, p<0.001$ ), and the differences were found between $100 \mathrm{~atm}$ and each of the other pressures $(p<0.001)$.

The percentage of time spent emerging was also significantly affected by pressure $(F=5.350, p=0.003)$, with the highest values at $100 \mathrm{~atm}$ at 10,15 and $20^{\circ} \mathrm{C}$ (Fig. 11). However, the percentage of time spent emerging was highest at $5{ }^{\circ} \mathrm{C}$ at all pressures except for $100 \mathrm{~atm}$ where no emerging behaviour was displayed. At $100 \mathrm{~atm}$ the highest average percentage of time spent emerging was at $20{ }^{\circ} \mathrm{C}$ at $19.40 \pm 32.42 \%$. Significant differences also lay between $100 \mathrm{~atm}$ and each other pressure $(p<0.004)$. In a single individual at $5{ }^{\circ} \mathrm{C}$, the crab removed itself entirely from its shell and then remained completely exposed for the duration, mid-way through the $20 \mathrm{~min}$ spent at $20 \mathrm{~atm}$.

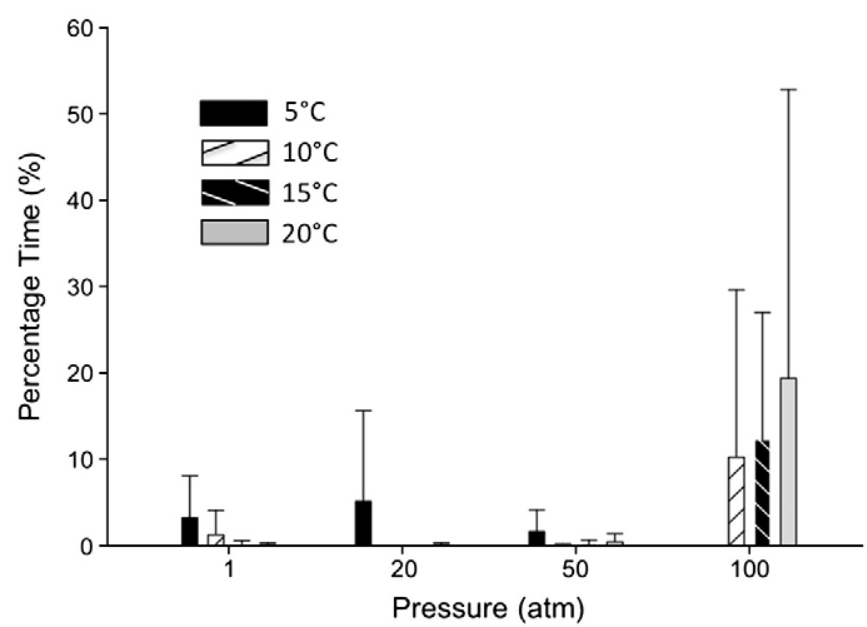

Fig. 11. Pagurus cuanensis. Percentage of time spent in the emerging state under different temperature and pressure conditions; ( $N=5$ in each treatment). 


\section{Discussion}

\subsection{Influence of pressure and temperature on the SMR}

The SMR in P. cuanensis is positively correlated with temperature when pressure was not a contributing factor, similar to previous research into crustacean metabolic rate (Stillman and Somero, 1996; Alekseeva and Zotin, 2001). The little overall effect of increased pressure on SMR at the lower three temperatures $\left(5,10\right.$ and $\left.15^{\circ} \mathrm{C}\right)$ suggests that temperature is the more dominant factor affecting oxygen consumption. However, at higher pressures the difference of SMR with temperature resulted in a distinctly smaller range. This is in contrast with the results of Childress (1977), who found that in the mid-water copepod Gaussia princeps oxygen consumption was more sensitive to temperature at higher pressures. Teal (1971) demonstrated that for some vertically migrating decapods, decreasing metabolism brought about by lower temperatures was offset by an increase in metabolism related to higher pressures, potentially as an adaption to maintain predatory behaviour at depth. It is possible that $P$. cuanensis undertakes a similar regulatory practice when subjected to hydrostatic pressure. Hermit crabs have previously demonstrated only a temporary increase in oxygen consumption when subjected to stressful conditions (i.e. salinity stress; Shumway, 1978). It is therefore possible that an increase in pressure may produce the same result of only a temporary metabolic increase that would not be measurable with the techniques used within this study. This would also suggest acclimation to pressure, at least in the short term and/or an attempt to maintain the normal metabolic rate, which implies an additional energetic cost. In addition, activity in hermit crabs results in greater oxygen consumption (Herreid and Full, 1986). Strenuous activity i.e. hermits attempting to free their shell from the dental wax, decreased significantly at $100 \mathrm{~atm}$. This was not correlated with a decrease in SMR at the same pressure, possibly a result of the balance between decrease in SMR related to reduced activity and an increase in SMR related to pressure stress. The low SMR found at all pressures at the temperature indicative of the deep sea $\left(5^{\circ} \mathrm{C}\right)$ suggests that the hermit crabs would be capable of only limited activity at depth implying a potentially unviable lifestyle.

\subsection{Influence of hydrostatic pressure and temperature on behaviour}

The behaviour of organisms can represent a direct or indirect response to unfavourable conditions. Individuals of $P$. cuanensis demonstrated numerous behavioural changes when subjected to changes in hydrostatic pressure.

The high rate of wiping of the scaphognatites and antennules at both 5 and $20^{\circ} \mathrm{C}$ at atmospheric pressure may be a consequence of temperature stress as the antennules bear sensory setae (Ingle, 1993). At $20^{\circ} \mathrm{C}$, an increased rate of wiping of these appendages occurred, which may imply stress or increased activity with higher temperatures. At $100 \mathrm{~atm}$ the mean rate of wiping of the scaphognatites and antennules increased with temperature up to $15^{\circ} \mathrm{C}$ but at $20^{\circ} \mathrm{C}$ the rate was restrained to that displayed at the previous two pressures, suggesting that the individuals reach a maximum wiping rate at this temperature when subjected to pressures $20 \mathrm{~atm}$ and above, as energy may be reserved for maintaining more basic functions.

The rate of wiping of the antennae with the third maxillipeds revealed two very distinct patterns. The antennae also bear sensory setae (Ingle, 1993) and so may indicate a response to stressful conditions. At the lowest and highest pressures the rate of wiping of the antennae followed remarkably similar relationships with temperature. The lowest rate of wiping at $10{ }^{\circ} \mathrm{C}$ suggests the optimal or least stressful temperature, while the rate of wiping then increased from 5 to 15 to $20^{\circ} \mathrm{C}$, possibly indicating increasing levels of both low and high of temperature stress. However, at 20 and $50 \mathrm{~atm}$ the rate of wiping was increased to an apparent maximum equal rate at all tem- peratures, implying pressure stress regardless of temperature. The lack of this display of maximum wiping rate at $100 \mathrm{~atm}$ may be a result of energy being directed elsewhere, as previously suggested. However, a further possibility is that high hydrostatic pressure impairs the function of the mechanoreceptor sensory setae on the antennae, resulting in the rate of wiping being related solely to the metabolic rate and temperature, as found at atmospheric pressure.

Hermit crabs can withdraw into gastropod shells for protection from environmental factors such as predation, desiccation, extremes of salinity and competition for shells from other individuals (Elwood, 1995; Pechenik et al., 2001); retraction of a hermit crab into its shell may be viewed as a defensive behaviour. The significant increase in the number of withdrawals into the shell per minute at $100 \mathrm{~atm}$ strongly suggests that the crabs can sense and become agitated by high-pressure conditions. This is supported by the increase in the amount of time spent emerging at $100 \mathrm{~atm}$, a result of both the induced withdrawal response and a possible insecurity under the conditions causing rapid alterations in decisions. This reaction to high pressure however, was not displayed at $5{ }^{\circ} \mathrm{C}$, where three individuals remained exposed and two remained withdrawn the entire time. This demonstrates that the effect of pressure was more distinct at lower temperatures, either causing the withdrawal response to be maintained for the duration or not at all. The cause of this discrepancy is unknown, but is possibly due to the low temperature combined with high pressure impairing decision-making abilities, or stimulating an altered behaviour.

Length of time spent in shell has been suggested to relate to motivation (e.g. hunger combined with a startle stimulus, Elwood et al., 1998). Billock and Dunbar (2009) found that when both deprived of a shell and starved, the hermit crab Pagurus samuelis was more motivated to find a shell than food, demonstrating the importance of the protective shell. Additionally, hermit crabs are known to withdraw into the shell when subjected to both low salinity and low oxygen conditions (Lancaster, 1988). In agreement with this, the distinct increase of the length of time spent within the shells at 100 atm suggests that the motivation to adopt this position as a defensive response to pressure is greater than the motivation to attempt to escape from the conditions. Many individuals remained withdrawn for the duration of the exposure at the highest pressure, and for a significant period following, which included depressurisation at a similar rate to the previous pressurisation. Reese (1969) argued that the shells of hermit crabs act as a microhabitat, which increases physiological tolerances to, or removes the individual from extreme conditions. However, while withdrawn the individual forsakes the opportunity to undertake activities such as feeding and mating. This suggests that while all animals tolerated the high-pressure conditions in the short term, the typical lifestyle would not be possible, rendering long-term survival at $1000 \mathrm{~m}$ depth unviable.

The use of behaviours to maintain homeostasis in decapod crustaceans has been explored (e.g. Huntingford et al., 1995 and references therein). For example, increased swimming activity has been observed in the larvae of the hermit crab Discorsopagurus schmitti as a result of increasing pressure (Gherardi, 1995). Shumway (1978) found that exposing hermit crabs to low salinities resulted in increased activity, most likely in an attempt to move away from the unfavourable conditions, and only withdrew into the shell when escape was impossible. This may explain the increase in the percentage of time spent attempting to escape from the dental wax which restrained movement of the shell at all temperatures from 1 to $20 \mathrm{~atm}$, as the greater pressure could motivate the crab to increase energy spent endeavouring to maintain itself within its optimal depth distribution. In addition, the exposed position in which the experimental animals were fixed in order to maintain observation of behaviours would, in the natural environment, render them vulnerable to predation. This evidently explains the relatively high amount of time invested in attempting to free itself. However, increased activity results in higher 
oxygen consumption and therefore energetic cost (Herreid and Full, 1986). It is likely that the decrease in the escaping behaviour at higher pressure may be due to energy being reserved for maintaining basic functions such as respiration, with freeing its protective shell no longer the priority. In nature, this would result in the individual no longer capable of, or primarily motivated to remove itself from the detrimental conditions.

Under high pressure and low temperature conditions, it was also noted in some individuals that movements became distinctly robotic, resulting in tremors. This behaviour has been noted previously for shallow-water species (Brauer, 1984; Wilcock et al., 1978), and is thought to be a symptom of high-pressure neurological syndrome (Somero, 1992). As pressure had different behavioural effects at varying pressures, it is suggested that there is a hierarchy in the stress responses of $P$. cuanensis when subjected to pressure.

\subsection{Distribution and radiation of the Anomura}

The evolutionary history of the Anomura has long been controversially discussed (McLaughlin and Lemaitre, 1997, and references therein). An interesting aspect to the separation of the families of the Lithodidae and Paguridae is the differences in the distribution, both horizontally and vertically. While there are large overlaps in the distribution of the families, each contains species, which inhabit environments inaccessible to the other. For example, there are species of hermit crab, which are terrestrial and they are commonly found in tropical regions (e.g. Hazlett, 1981). In contrast, there are no terrestrial king crabs, and there is a limit to the temperature range with a maximum of about $16{ }^{\circ} \mathrm{C}$ for successful larval development (Hall and Thatje, 2009). The Lithodidae are divided into two sub-families, Hapalogastrinae and Lithodinae. The Hapalogastrinae are constrained to the North Pacific and inhabit depths less than $200 \mathrm{~m}$, yet the Lithodinae are distributed globally, with a maximum temperature threshold of $13{ }^{\circ} \mathrm{C}$, resulting in a deeper distribution to greater than $3000 \mathrm{~m}$, and intertidal species being found only at high latitudes (Hall and Thatje, 2009). This intolerance to high temperatures resulted in the radiation of the Lithodinae from the North Pacific through the deep sea to avoid the high temperatures (Zaklan, 2002). Therefore the spread of the Lithodinae occurred through a temperature bottleneck (Hall and Thatje, 2009). This is fundamentally similar to the pattern of increasing depth distribution of $P$. cuanensis with movement southwards in the North Atlantic (Forest, and Guinot, 1956; Ingle, 1993). While some species of hermit crab exist in the deep sea, the vast majority is found in intertidal or sub tidal habitats (Selbie, 1921; Wolff, 1961). Data from the present study demonstrate that the depth range of a hermit crab can be markedly smaller than its scope of physiological tolerance to pressure may suggest. A possible reason for the greater success of deep-sea existence of the Lithodinae is the adaptation of having a strongly calcified exoskeleton, negating the need for gastropod shell protection, a resource, which becomes limited with depth. This is further supported by the radiation into the deep sea by the fully armoured Lithodinae, but the restriction to depths not more than $200 \mathrm{~m}$ of the soft abdomened Hapalogastrinae (Zaklan, 2002; Hall and Thatje, 2009).

The SMR of $P$. cuanensis was substantially reduced at $5{ }^{\circ} \mathrm{C}$, suggesting that intolerance to cold water may inhibit radiation into deeper habitats. In addition, deep-sea lithodids must have evolved to effectively tolerate high hydrostatic pressure. The behaviour of P. cuanensis at $100 \mathrm{~atm}$, representative of $1000 \mathrm{~m}$, indicated that hydrostatic pressure had detrimental effects on the individuals. The Lithodidae are suggested to be descendent from a shallow-water, cold-eurythermal population in the North-East Pacific (Hall and Thatje, 2009), agreeing with the hypotheses of near shore to offshore evolution (Jablonski et al., 1983). If the Lithodidae and Paguridae have a common ancestor, evolution of divergent traits and physiological tolerances are most likely to have led to dissimilarities in the distribution of these families.
It is therefore hypothesized that differences in physiological tolerances to temperature and pressure combined and the limiting effect of the necessity of locating shells for protection, are among the main causes for the disparity in the geographical and bathymetric range of the families.

\section{Acknowledgements}

This work was supported by a grant (Abyss2100) from the Total Foundation to Sven Thatje, and a Royal Society visiting scientist grant to Javier A. Calcagno. The authors wish to thank Antony Jensen for his help in obtaining the hermit crabs. [SS]

\section{References}

Alekseeva, T.A., Zotin, A.I., 2001. Standard metabolism and macrotaxonomy of crustaceans. Biol. Bull. 28, 157-162.

Baeza, J.A., Fernández, M., 2002. Active brood care in Cancer setosus (Crustacea: Decapoda): the relationship between female behaviour, embryo oxygen consumption and the cost of brooding. Funct. Ecol. 16, 241-251.

Benson, B., Krause, D., 1984. The concentration and isotopic fractionation of oxygen dissolved in fresh-water and seawater in equilibrium with the atmosphere. Limnol. Oceanogr. 29 (3), 620-632.

Billock, W.L., Dunbar, S.G., 2009. Influence of motivation on behaviour in the hermit crab, Pagurus samuelis. J. Mar. Biol. Assoc. UK 89, 775-779.

Brauer, A.W., 1984. Hydrostatic pressure effects on the central nervous system: perspectives and outlook. Philos. Trans. R. Soc. London Ser. B. 304 (1118), 17-30.

Brauer, RW. Beaver, R.W. Mansfield, W.M. O'Connor, F. White, L, 1975. Rate factors in the development of the high pressure neurological syndrome. J. Appl. Physiol. 38, 220-227.

Briffa, M., Elwood, R.W., 2005. Metabolic consequences of shell choice in Pagurus bernhardus: do hermit crabs prefer cryptic or portable shells? Behav. Ecol. Sociobiol. $59,143-148$

Carney, R.S., Haedrich, R.L., Rowe, G.T., 1983. Zonation of fauna in the deep sea. In: Rowe, G.T. (Ed.), The Sea. : Deep-Sea Biol., vol. 8. Wiley, New York, pp. 371-398.

Childress, J.J., 1977. The effects of pressure, temperature and oxygen on the oxygen consumption rate of the midwater copepod Gaussia princeps. Mar. Biol. 39, 19-24.

Cunningham, C.W., Blackstone, N.W., Buss, L.W., 1992. Evolution of king crabs from hermit crab ancestors. Nature 355, 539-542.

Elwood, R.W., 1995. Motivational change during resource assessment by hermit crabs. J. Exp. Mar. Biol. Ecol. 193, 41-55.

Elwood, R.W., Wood, K., Gallagher, M., Dick, J.T.A., 1998. Probing motivational state during agonistic encounters in animals. Nature 393, 66-68.

Feldmann, R.M., 1998. Paralomis debodeorum, a new species of decapod crustacean from the Miocene of New Zealand: first notice of the Lithodidae in the fossil record. NZ J. Geol. Geophys. 41, 35-38.

Forest, J., Guinot, D., 1956. Sur une collection de Crustacés Décapodes et Stromatopodes de mers tunisiennes. Bull. Stn. Océanog. Salammbô 53, 24-43.

Gage, J.D., Tyler, P.A., 1991. Deep sea biology: a natural history of organisms at the deep sea floor. Cambridge University Press, Cambridge.

Gherardi, F., 1995. Hermit crab larval behavior: depth regulation in Discorsopagurus schmitti Forest, J., 1955 Crustacés Décapodes, Pagurides. J. Exp. Mar. Biol. Ecol. 192, 107-123.

Hall, S., Thatje, S., 2009. Global bottlenecks in the distribution of marine Crustacea: temperature constraints in the family Lithodidae. J. Biogeogr. 36, 2125-2135.

Hazlett, B.A., 1981. The behavioural ecology of hermit crabs. Ann. Rev. Ecol. Syst. 12, $1-22$.

Herreid, C.F., Full, R.J., 1986. Energetics of hermit crabs during locomotion: the coast of carrying a shell. J. Exp. Biol. 120, 297-308.

Huntingford, F.A., Taylor, A.C., Smith, I.P., Thorpe, K.E., 1995. Behavioural and physiological studies of aggression in swimming crabs. J. Exp. Mar. Biol. Ecol. 193, 21-39.

Ingle, R., 1993. Hermit crabs of the Northeastern Atlantic Ocean and the Mediterranean Sea. British Museum (Natural History). Chapman \& Hall, London. 495 pp.

Jablonski, D., Sepkoski, J.J., Bottjer, D.J., Sheehan, P.M., 1983. Onshore-Offshore patterns in the evolution of phanerozoic shelf communities. Science 222, 1123-1125.

Jaenicke, R., 1983. Biochemical processes under high hydrostatic pressure. Naturwissenschaften 70, 332-341.

Lancaster, I., 1988. Pagurus bernhardus - an introduction to the natural history of the hermit crabs. Field Stud. 7, 189-238.

Martin, JW., Abele, L.G., 1986. Phylogenetic relationships of the genus Aegla (Decapoda: Anomura: Aeglidae), with comments on anomuran phylogeny.J. Crust. Biol. 6, 576-616.

McGaw, I.J., Duff, S.D., 2008. Cardiovascular system of anomuran crabs, genus Lopholithodes. J. Morphol. 269, 1295-1307.

McLaughlin, P.A. 1983. Hermit crabs - are they really polyphyletic? J. Crust. Biol. 3, 608-621.

McLaughlin, P.A., Lemaitre, R., 1997. Carcinization in the Anomura - fact or fiction? I. Evidence from adult morphology. Contr. Zool. 67, 79-123.

McLaughlin, P.A. Lemaitre, R., Tudge, C.C., 2004. Carcinization in the Anomura - fact or fiction? II. Evidence from larval, megalopal and early juvenile morphology. Contr. Zool. 73, 165-205.

McLaughlin, P.A., Lemaitre, R., Sorhannus, U., 2007. Hermit crab phylogeny: a reappraisal and its "fall-out". J. Crust. Biol. 27, 97-115. 
Mestre, N., Thatje, S., Tyler, P.A., 2009. The ocean is not deep enough: pressure tolerances during early ontogeny of the blue mussel Mytilus edulis. Proc. Roy. Soc. B 276, 717-726.

Milne Edwards, H., 1836. Observations zoologiques sur les Pagures et description d'un nouveau genre de la tribu des Paguriens. Annals. Sci. Nat. Zool. 2, 257-288.

Pechenik, J.A., Hsieh, J., Owara, S., Wong, P., Marshall, D., Untersee, S., Li, W., 2001. Factors selecting for avoidance of drilled shells by the hermit crab Pagurus longicarpus. J. Exp. Mar. Biol. Ecol. 262, 75-89.

Ravaux, J., Gaill, F., Le Bris, N., Sarradin, P.-M., Jollivet, D.B., Shillito, B., 2003. Heat-shock response and temperature resistance in the deep-sea vent shrimp Rimicaris exoculata. J. Exp. Biol. 206, 2345-2354.

Reese, E.S., 1969. Behavioral adaptations of intertidal hermit crabs. Am. Zool. 9, 343-355.

Robinson, N.J., Thatje, S., Osseforth, C., 2009. Heartbeat sensors under pressure: a new method for assessing hyperbaric physiology. High Pressure Res. 29, 422-430.

Saunders, G.W., Druehl, L.D., 1992. Nucleotide sequences of the small-subunit ribosomal RNA genes from selected Laminariales (Phaeophyta): implications for kelp evolution. J. Phycol. 28, 544-549.

Selbie, C.M., 1921. The Decapoda Reptantia of the coasts of Ireland. Part II. Paguridae. Sci. Invest. Fish. Board Ireland 1, 1-68.

Shillito, B., Jollivet, D., Sarradin, P.-M., Rodier, P., Lallier, F., Desbuyères, D., Gaill, F., 2001. Temperature resistance of Hesiolyra bergi, a polychaetous annelid living on deepsea vent smoker walls. Mar. Ecol. Prog. Ser. 216, 141-149.

Shumway, S.E., 1978. Osmotic balance and respiration in the hermit crab, Pagurus bernhardus, exposed to fluctuating salinities. J. Mar. Biol. Assoc. U.K. 58, 869-876.

Sokal, R.R., Rohlf, F.J., 1995. Biometry. The principles and practice of statistics in Biological Research. Freeman, New York, NY. 887 pp.
Somero, G.N., 1992. Adaptations to high hydrostatic pressure. Annu. Rev. Physiol. 54 557-577.

Southward, A.J., Hawkins, S.J., Burrows, M.T., 1995. Seventy years' observations of changes in distributions and abundance of zooplankton and intertidal organisms in the western English Channel in relation to rising sea temperature. J. Therm. Biol. 20, 127-155.

Stillman, J.H., Somero, G.N., 1996. Adaptation to temperature stress and aerial exposure in congeneric species of intertidal porcelain crabs (genus Petrolisthes): correlation of physiology; biochemistry and morphology with vertical distribution. J. Exp. Biol 199, 1845-1855.

Teal, J.M., 1971. Pressure effects on the respiration of vertically migrating decapod Crustacea. Am. Zool. 11, 571-576.

Tyler, P.A., Young, C.M., 1998. Temperature and pressure tolerances in dispersal stages of the genus Echinus (Echinodermata: Echinoidea): prerequisites for deep-sea invasion and speciation. Deep-Sea Res. II 45, 253-277.

Underwood, A.J., 1981. Techniques of analysis of variance in marine biology and ecology. Oceanogr. Mar. Biol. Annu. Rev. 19, 513-605.

Wilcock, S.E., Wann, K.T., MacDonald, A.O., 1978. The motor activity of Crangon crangon subjected to a high hydrostatic pressure. Mar. Biol. 45, 1-7.

Wolff, T., 1961. Description of a remarkable deep-sea hermit crab with notes on the evolution of the Paguridae. Galath. Rep. 4, 11-32.

Zaklan, S.D., 2002. Review of the family Lithodidae (Crustacea: Anomura: Paguroidea): distribution, biology and fisheries. Crabs in Cold Water Regions: Biology, Management and Economics. Alaska Sea Grant College Program, Fairbanks, Alaska, pp. 58-845. 